\title{
A Review of Structure and Function of Primary Health Care System in Islamabad, Pakistan
}

\author{
Muhammad Naveed Babur* \\ Rehabilitation Sciences, ISRA University, Pakistan
}

Submission: January 17, 2018; Published: June 22, 2018

*Corresponding author: Muhammad Naveed Babur, PhD, Rehabilitation Sciences, Principal, Isra Institute of Rehabilitation Sciences, Isra University, Islamabad campus, Pakistan, Email: naveedphysio@gmail.com

\section{Introduction}

Islamabad, the capital city of Pakistan, has been ranked second in the list of world's most beautiful capital. It is located on Pothohar Plateau, in the north of Pakistan. In 1959 Islamabad was chosen to be the new capital of Pakistan and the city was built in 1960. Though it is situated between Khyber Pakhtunkhwa and Punjab, yet it is not the part of any of these provinces [1]. Area of Islamabad is 910 square kilometers and its population, according to housing survey 2011 by consensus department, is around 2 million out of which $66 \%$ is urban and $34 \%$ is rural [2]. It is governed by the Federal Government of Pakistan. Islamabad is one of the two Federal territories. The Islamabad Capital territory (ICT) and the other one is Federally Administrate Tribal Area (FATA).

Administratively Islamabad is divided into two parts. Urban Islamabad and Rural Islamabad an Urban area is comprised of Islamabad city and rural area consists of twelve union councils. These are Rawat, Sehala, Koral, Tarlai Kalan, Kirpah, Chirah, Tumair, Phulgaran, Bharakahu, Kuri, Soaan and Shah Allah Ditta. Total numbers of villages are 133 in all union councils collectively [3]. In 1960 CDA was created to oversee administrative and organizational matter of the newly formed city. Since then many structural and directorial changes have taken place in CDA and now it is also playing a role of Executive Authority in the Capital city [4]. Capital Developmental Authority (CDA) is responsible for delivery of municipal services in Islamabad. Various departments which are administered by ICT are Auqaf department, Local Government and rural development, Excise and Taxation department, Health department, District attorney Department, Cooperative society department, Civil Defense department and Cooperative society department.

ICT administration works under the supervision of Chief Commissioner. The chain of command of Chief Commissioner of Islamabad is subdivided into Director Development and finance, Director Industries and labor, Director Admin, Director Agriculture, Inspector General of Police and Deputy Commissioner. After $18^{\text {th }}$ constitutional amendment in 2010 many ministries working under federal government got devolved and provincial autonomy was strengthened. Capital administration and development division was formed to carry out various functions of the capital city which were executed by abolished ministries previously. Federal ministry of health also got devolved and the health related management services in the capital city were handed over to the Ministry of Capital Administration and Development Division (CADD). In Urban Islamabad CADD is responsible to manage different departments. Various organizations like Education Directorate, National Council of social welfare, Directorate General of Special Education, Islamabad club, National Institute of Rehabilitation medicine, Pakistan institute of medical sciences, Poly clinic, CDA hospital etc are affiliated to CADD. In rural Islamabad the office of Deputy Commissioner is responsible for carrying out and managing various projects in different union councils.

The Primary health care system is backbone of any nation. In developing countries like Pakistan, where a major chunk of population is residing in rural areas, developing PHC is very important. Health care provision to every citizen of Pakistan is the state's responsibility. But unfortunately majority of people here are affording health out of their own pockets [5].

A common perception is that Islamabad being the federal capitol should be the model which should be replicated, however, despite its small size in both territorial and population terms although being endowed with adequate financial resources the provision of health services in the suburbs is not satisfactory. In Pakistan health care delivery system was centralized before the $18^{\text {th }}$ constitutional amendment. After devolution the provincial health sectors got strengthened as they were given autonomy where as health sector of the Capital of Pakistan got badly fragmented and weakened. Out of three tiers Primary health care system was affected most. BHUs and RHCs which were working under a central command previously are highly neglected now.

The worst part is that LHW program which is losing its effectiveness. To reform and strengthen primary health sector is a need of the time. A disorganized system has increased burden on tertiary care hospitals which are meant to deliver specialized services and thus quality of health care delivery is falling down. The present state of affairs speaks volumes about 
the apathy and indifference of governing bodies. Whether this is by design or default is not important. What is important is that no concerted effort visibly is being done which remains the prime responsibility of the Ministry of Interior. Government should take positive steps to strengthening Primary health care system of Islamabad. Administrative structure should be streamlined financial constrained should be resolved to improve basic physical infrastructure and overcome the lack of human resource.

\section{References}

1. http://www.islamabadthecapital.com/islamabad/

2. Irfan R (2012) Islamabad's population-DAWN News.

3. https://en.wikipedia.org/wiki/Islamabad

4. http://www.cda.gov.pk/

5. Importance and relevance of primary health care. 